\title{
Carbon Dioxide Emission Peak and Green Innovation-Driven Research of Escaping Middle Income Trap for China
}

\author{
Jianya Liu ${ }^{l}$, Zhenqing Sun ${ }^{1,}$, Zirui Lan ${ }^{1,2}$ and Chunxiao Kou ${ }^{1}$ \\ ${ }^{1}$ School of Economic and Management, Tianjin University of Science and Technology, Tianjin, 300222, China \\ ${ }^{2}$ School of Economics and Business, Norwegian University of Life Science, As 1432, Norway
}

\begin{abstract}
This study explains and demonstrates whether China has the capability to avoid the Middle Income Trap. The 19th National Congress of CPC report points out: by 2035, China will become an international leader in innovation. At present, China is in the juncture of changing the mode of development, optimizing the economic structure and transforming the growth momentum. The juncture means that it is possible to be stagnation or retrogression of national economy as the national ability of innovation is insufficient, then sticking in the middle-income trap (MIC) for a long time. In this paper, we used the TFP to prove that the input-output ratio of different regions of China, with the per capita GDP and carbon emissions are fitting again, dividing China into optimized zones and non-optimized zones. It can be seen from the results that the optimized zones have achieved the peak of carbon emission and had relative advantages in green innovation. However, if China wants to achieve her overall carbon emissions and get out of the middle income trap, she must optimize the development zones to spillover technologies and talents.
\end{abstract}

\section{Introduction}

The climate issue has been becoming a focus of attention, and the Copenhagen conference in 2009 had written target that limit the 2 centigrade degrees rise into protocol. The 2015 Paris agreement is clearer about the temperature rise of 2 centigrade degrees, and as much as possible to meet the requirements of 1.5 centigrade degrees. In June 2015, China committed its goal of independent action to the United Nations: emissions of carbon dioxide would reach the peak by 2030 as soon as possible; the emissions of carbon dioxide per unit of gross domestic production would be decreased by $60 \%$ $65 \%$ that would be compared with that in 2005 . Under the aid of pressure of reaching peak, on the one hand, we should explore the system of driving innovation and development, and on the other hand, we should explore the path of crossing the "middle income trap" firstly.

China put forward the economic development strategy of Chinese Economic Reform and opens up since 1980, so the per capita GDP had been advanced from the end of the world to the middle income countries by 2007. China's economy has been entering a period of rapid development since 1980 . But by the other countries' development experience, when a country's economy reaches middle income level, its economy is in a long-term stagnation due to various reasons and economic growth rate is slowing down obviously. In 30 years of rapid development by reform and opening up policy, China had successfully entered into Medium and high income countries. And the next goal is that China would enter the ranks of high-income countries. Although China's economy has been growing at a high speed for many years, the middle income trap is a problem that has to be faced.

\section{Theories}

When a country's economy has reached the level of middle income, her economy has been in a long-term stagnation and growth rate has slowed down as a variety of reasons, which is the most vulnerable stage for economic development. The World Bank (WB) calls this stage is a "Middle Income Trap (MIC)" [1]. In 2017, the latest WB income standard [2]: per capita GDP, $1006 \sim 12235$ in current price of the US dollar is middle income, it means that high income is higher than 12235 US dollars, and 3955 US dollars is a boundary of middle upper and lower.

In 2008, China's per capita GDP firstly exceeded $\$ 3000$, entering the level of middle-income countries. Whether the slowdown in economic growth has fallen into the middle income trap or not, which has attracted the attention of all walks of life. Kharas ${ }^{[3]}$ believed that China would face the risks of falling into the middleincome trap. Hogo Erken ${ }^{[4]}$ proposed to cross the middle-income trap by relying on total factor productivity (TFP), especially the productivity related to upgrading technologies. Barry Eichengree (2012) [5], based on Korean's experience, found that high income countries' economic growth was largely driven by TFP. The research found that the driving factor of TFP growth

\footnotetext{
* Corresponding author: sunzq@tust.edu.cn
} 
was research and development (R\&D), and the increase of R\&D by $1 \%$ (the proportion of industrial added value) would increase the TFP growth rate of the corresponding industry by $0.13 \%$. With the development of measurement technology and data collection, the research of TFP has expanded from macro field to industry and enterprise level, which is also fit for China ${ }^{[6]}$. Brandt etc (2012) ${ }^{[7]}$ had found that China's TFP had been improved based on empirical analysis. The growth of China's economy over the past 30 years has not just depended on capital input.

Schumpeter (1912) is the first person to put forward the "innovation theory" in the perspective of technology and economy, emphasizing the important role of production technology innovation in the process of economic development. Nicholas Bloom (2013) ${ }^{[8]}$ used a patent technology to measure the technological activity of every company in a period, and then used technology standard to measure the spillover effect of R\&D.

\section{Models}

\subsection{Calculations Model and Research Method}

It is assumed that the production system has a number of $\mathrm{n}$ decision making units (DMU), which are represented as $\mathrm{DMU}_{\mathrm{j}}(\mathrm{j}=1,2, \ldots, \mathrm{n})$. Respectively, $\mathrm{x}$ and $\mathrm{y}$ represents input and output variables, $\mathrm{m}$ and $\mathrm{r}$ is the number of input and output variables. ${ }^{-}$Represents the slack variable, which be denoted by input excess. Each DMU consumes $\mathrm{m}$ inputs of $\mathrm{X}_{\mathrm{ij}}(\mathrm{i}=1,2, \ldots, \mathrm{m})$, production is the number of $\mathrm{s}_{1}$ expected outputs $\mathrm{Y}^{\mathrm{g}}$ and the number of $\mathrm{s}_{2}$ undesirable outputs $\mathrm{U}^{\mathrm{b}}$, so these can be expressed as $\mathrm{x} \in \mathrm{R}^{\mathrm{m}}, \quad \mathrm{y}, \mathrm{g} \in \mathrm{R}^{\mathrm{s} 1}, \mathrm{U}^{\mathrm{b}} \in \mathrm{R}^{\mathrm{s} 2}$. Define the matrix $\mathrm{X}, \mathrm{Y}^{\mathrm{g}}, \mathrm{U}^{\mathrm{b}}$ are as follows:

$$
\begin{aligned}
& \mathrm{X}=\left[\mathrm{x}_{1}, \ldots, \mathrm{x}_{\mathrm{n}}\right] \in \mathrm{R}^{\mathrm{m} \times \mathrm{n}} ; \\
& \mathrm{Y}^{\mathrm{g}}=\left[\mathrm{y}_{1}^{\mathrm{g}}, \ldots, \mathrm{y}_{\mathrm{n}}^{\mathrm{g}}\right] \in R^{s_{1} \times \mathrm{n}} ; \\
& \mathrm{U}^{\mathrm{b}}=\left[\mathrm{u}_{1}{ }^{\mathrm{b}}, \ldots, \mathrm{u}_{\mathrm{n}}{ }^{\mathrm{b}}\right] \in R^{s_{2} \times \mathrm{n}} \\
& \mathrm{X}>0, \quad \mathrm{Y}^{\mathrm{g}}>0, \quad \mathrm{U}^{\mathrm{b}}>0 .
\end{aligned}
$$

Under conditions of constant return to scale (CRS), the possible production that $\mathrm{P}$-sets is defined as:

$\mathrm{p}=\{(\mathrm{x}, \quad \mathrm{yg}, \quad \mathrm{ub}) \mid \mathrm{x} \geq \mathrm{X} \lambda, \quad \mathrm{yg} \leq \mathrm{Yg} \lambda, \quad \mathrm{ub} \geq \mathrm{Ub} \lambda, \quad \lambda \geq 0\}$

According to the SBM model proposed by Tone, it is obtained the SBM - Undesirable model, so the SBM model of undesired output under strong disposability is as follows:

$$
\rho^{*}=\min \frac{1-\frac{1}{\mathrm{~m}} \sum_{i=1}^{m} \frac{s_{i}^{-}}{x_{i o}}}{1+\frac{1}{s_{1}+s_{2}}\left[\sum_{r=1}^{s_{1}} \frac{s_{r}^{g}}{y_{r_{0}}^{g}}+\sum_{r=1}^{s_{2}} \frac{s_{r}^{b}}{u_{r_{0}}^{b}}\right]}
$$

$$
\text { s.t. }\left\{\begin{array}{l}
x_{0}=X \lambda+S^{-} \\
y_{0^{g}}=Y^{g} \lambda+S^{g} \\
U_{0}=U^{b} \lambda+S^{b} \\
s^{-} \geq 0 ; S^{g} \geq 0 ; S^{b} \geq 0 ; \lambda \geq 0
\end{array}\right.
$$

In those formulas: $s$ represents the slack variable of input and output; $\lambda$ represents the weight vector; $\rho^{*}$ represents the objective function, which meets $0 \leq \rho^{*} \leq 1$, $\mathrm{s}^{-}, \mathrm{s}^{\mathrm{g}}$ and $\mathrm{s}^{\mathrm{b}}$ are strongly decreasing. For specific DUMs, under the condition of that $\rho^{*}=1, \mathrm{~s}^{-}=0, \mathrm{~s}^{\mathrm{g}}=0, \mathrm{~s}^{\mathrm{b}}=0$, which are efficient ; if $\rho^{*}<1$, it indicates that the DUMs are inefficient, which have the need of improving input and output.

\subsection{Index selection and data source}

As data of the regions of Tibet, Hongkong, Macao and Taiwan could not search, this study uses China's 30 provincial regional input-output panel data from 2005 to 2015 as the sample, which are from the year of 2006 to 2016 by Yearbooks including "China Statistical Yearbook", "Chinese City Statistical Yearbook", "China

\begin{tabular}{|c|c|c|c|}
\hline index & Sub-index & $\begin{array}{l}\text { Measurement } \\
\text { index }\end{array}$ & unit \\
\hline \multirow[t]{7}{*}{ input } & Capital input & Capital stock & $\begin{array}{c}\text { Million } \\
\text { yuan }\end{array}$ \\
\hline & \multirow[t]{2}{*}{ Labor input } & $\begin{array}{l}\text { R\&D people } \\
\text { number }\end{array}$ & per \\
\hline & & $\begin{array}{l}\text { The number of } \\
\text { people engaged in } \\
\text { water conservancy, } \\
\text { urban environment } \\
\text { and public service. }\end{array}$ & per \\
\hline & \multirow[t]{3}{*}{$\begin{array}{l}\text { Resource } \\
\text { input }\end{array}$} & $\begin{array}{l}\text { The volume of } \\
\text { water supply }\end{array}$ & $\begin{array}{c}\text { Thousa } \\
\text { nd } \\
\text { stere }\end{array}$ \\
\hline & & $\begin{array}{l}\text { Total electricity } \\
\text { consumption }\end{array}$ & $\begin{array}{l}\text { Million } \\
\text { kilowat } \\
\mathrm{t} \text { hour }\end{array}$ \\
\hline & & $\begin{array}{l}\text { The total gas } \\
\text { supply of liquefied } \\
\text { petroleum gas. }\end{array}$ & ton \\
\hline & Energy input & $\begin{array}{c}\text { Energy } \\
\text { consumption }\end{array}$ & tce \\
\hline \multirow[t]{7}{*}{ output } & Economic & GDP & $\begin{array}{c}\text { Million } \\
\text { yuan }\end{array}$ \\
\hline & \multirow[t]{2}{*}{$\begin{array}{l}\text { Technology } \\
\text { output }\end{array}$} & $\begin{array}{c}\text { New product sales } \\
\text { revenue. }\end{array}$ & $\begin{array}{c}\text { Thousa } \\
\text { nd } \\
\text { yuan }\end{array}$ \\
\hline & & $\begin{array}{c}\text { Number of patents } \\
\text { granted }\end{array}$ & piece \\
\hline & \multirow[t]{2}{*}{ Green output } & Green land area & hectare \\
\hline & & The park area & hectare \\
\hline & \multirow{2}{*}{$\begin{array}{c}\text { Environmental } \\
\text { pollution } \\
\text { output }\end{array}$} & $\begin{array}{c}\text { Industrial SO2 } \\
\text { emissions. }\end{array}$ & $\begin{array}{l}\text { Million } \\
\text { tons }\end{array}$ \\
\hline & & Industrial & ton \\
\hline
\end{tabular}
Statistical Yearbook on Science and Technology ", "Data of Gross Domestic Product of China(the year of 19522004)" and "Chinese Energy Statistical Yearbook" as the original data and the calculated results (Table1).

Table1. The index of input and output. 


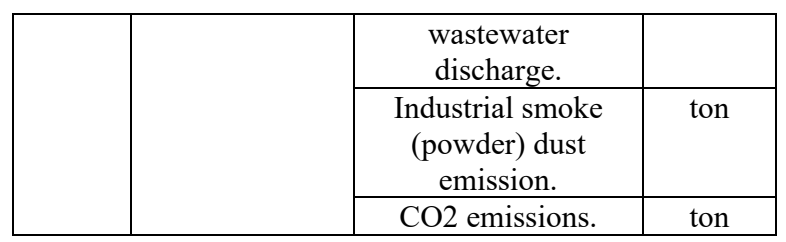

The input-output indexes are treated with the maximum minimum value method, and the statistical description of input-output in China is obtained (Table 2).

Table 2. Statistical description of input-output in China.

\begin{tabular}{|c|c|c|c|c|c|c|c|c|}
\hline & capital & labor & $\begin{array}{l}\text { resour } \\
\text { ce }\end{array}$ & $\begin{array}{l}\text { energ } \\
\mathbf{y}\end{array}$ & $\mid \begin{array}{l}\text { environ } \\
\text { mental } \\
\text { pollutio } \\
\text { n }\end{array}$ & $\begin{array}{l}\text { econo } \\
\text { my }\end{array}$ & $\begin{array}{l}\text { techn } \\
\text { ology }\end{array}$ & green \\
\hline Max & \begin{tabular}{|l}
534 \\
86. \\
38 \\
\end{tabular} & $\left|\begin{array}{l}3377 \\
10.01\end{array}\right|$ & $\begin{array}{l}15493 \\
152.9\end{array}$ & $\begin{array}{l}3817 \\
9.53\end{array}$ & $\begin{array}{l}91792 \\
3.28\end{array}$ & $\begin{array}{l}6089 \\
1.28\end{array}$ & $\begin{array}{l}49781 \\
620.5\end{array}$ & $\begin{array}{l}23444 \\
3.69\end{array}$ \\
\hline Min & $\begin{array}{l}1422.1 \\
8 \\
\end{array}$ & \begin{tabular}{|l}
5942.8 \\
0
\end{tabular} & \begin{tabular}{|l}
337484 \\
.93 \\
\end{tabular} & $\begin{array}{l}42124 . \\
91\end{array}$ & 2308.12 & $\begin{array}{l}1762 . \\
27 \\
\end{array}$ & $\begin{array}{l}22959 . \\
49\end{array}$ & $\begin{array}{l}2824 . \\
30 \\
\end{array}$ \\
\hline \begin{tabular}{|l} 
Aver \\
age
\end{tabular} & $\begin{array}{l}14540 . \\
94\end{array}$ & $\begin{array}{l}10623 \\
0.19\end{array}$ & $\begin{array}{l}341500 \\
2.57\end{array}$ & $\begin{array}{l}15597 \\
.29\end{array}$ & $\begin{array}{l}754943 . \\
85\end{array}$ & $\begin{array}{l}18955 \\
.35\end{array}$ & $\begin{array}{l}55892 \\
84.33\end{array}$ & $\begin{array}{l}43681 \\
.03 \\
\end{array}$ \\
\hline SD & $\begin{array}{l}11668 . \\
46\end{array}$ & $\begin{array}{l}84232 . \\
94\end{array}$ & $\begin{array}{l}303161 \\
4.96 \\
\end{array}$ & $\begin{array}{l}8836 . \\
86\end{array}$ & $\begin{array}{l}225389 . \\
72\end{array}$ & $\begin{array}{l}14932 \\
.34 \\
\end{array}$ & $\begin{array}{l}10263 \\
266.1\end{array}$ & $\begin{array}{l}44451 \\
15 \\
\end{array}$ \\
\hline
\end{tabular}

\subsection{Result}

By the DEA-Solver Pro 5 software, the input-output indexes are calculated by using the SBM-DEA model. The statistical results of carbon dioxide emission efficiency were shown in Table 3.

Table 3. Carbon dioxide emission efficiency.

\begin{tabular}{|c|c|c|c|c|c|c|c|c|c|}
\hline Area & $\begin{array}{l}\mathrm{CCR} / \mathrm{S} \\
\mathrm{BM}\end{array}$ & Area & $\begin{array}{l}\mathrm{CCR} / \mathrm{S} \\
\mathrm{BM}\end{array}$ & Area & $\begin{array}{l}\mathrm{CCR} / \mathrm{S} \\
\mathrm{BM}\end{array}$ & Area & $\begin{array}{l}\mathrm{CCR} / \mathrm{S} \\
\mathrm{BM}\end{array}$ & Area & $\begin{array}{l}\mathrm{CCR} / \\
\mathrm{SBM}\end{array}$ \\
\hline Beijing & $1 / 1$ & Liaoning & $\begin{array}{l}0.78 / 0 . \\
30\end{array}$ & $\begin{array}{l}\text { Zhejia } \\
\text { ng }\end{array}$ & $\begin{array}{l}0.96 / 0 \\
73\end{array}$ & Henan & $\begin{array}{l}0.93 / 0 . \\
58\end{array}$ & Hainan & $1 / 1$ \\
\hline Tianjin & $\begin{array}{l}0.96 / 0 \\
73\end{array}$ & Jilin & $\begin{array}{l}0.88 / 0 . \\
43\end{array}$ & Anhui & $1 / 1$ & Hubei & $\begin{array}{l}0.82 / 0 . \\
59 \\
\end{array}$ & $\begin{array}{l}\text { Chongq } \\
\text { ing }\end{array}$ & $1 / 1$ \\
\hline Hebei & $\begin{array}{l}0.86 / 0 . \\
35\end{array}$ & $\begin{array}{l}\text { Heilongj } \\
\text { iang } \\
\end{array}$ & $1 / 1$ & Fujian & 11 & Hunan & $1 / 1$ & \begin{tabular}{|l|l|} 
\\
Sichua
\end{tabular} & $1 / 1$ \\
\hline Shanxi & $\begin{array}{l}0.66 / 0 . \\
15\end{array}$ & Shanghai & $\begin{array}{l}0.99 / 1 . \\
00\end{array}$ & $\begin{array}{l}\text { Jiangx } \\
\mathrm{i}\end{array}$ & $1 / 1$ & $\begin{array}{l}\text { Guangd } \\
\text { ong }\end{array}$ & $1 / 1$ & \begin{tabular}{|l|} 
Guizho \\
$\mathrm{u}$
\end{tabular} & $\begin{array}{l}0.81 / . \\
034\end{array}$ \\
\hline $\begin{array}{l}\text { Neimen } \\
\text { ggu }\end{array}$ & $\begin{array}{l}0.66 / 0 . \\
08\end{array}$ & Jiangsu & $1 / 1$ & $\begin{array}{l}\text { Shand } \\
\text { ong }\end{array}$ & $\begin{array}{l}0.97 / 0 . \\
96\end{array}$ & $\begin{array}{l}\text { Guangx } \\
\text { i }\end{array}$ & $1 / 1$ & Yunnan & $1 / 1$ \\
\hline Shaanxi & $\begin{array}{l}0.62 / 0 . \\
32\end{array}$ & Gansu & $\begin{array}{l}0.57 / 0 . \\
15\end{array}$ & $\begin{array}{l}\text { Qingh } \\
\text { ai }\end{array}$ & $\begin{array}{l}0.73 / 0 \\
43\end{array}$ & Ningxia & $1 / 1$ & \begin{tabular}{|l|} 
Xinjian \\
$\mathrm{g}$
\end{tabular} & $1 / 1$ \\
\hline
\end{tabular}

From table 3 we can see that the half of the Chinese efficiency value is 1 , which indicated that Chinese serious carbon dioxide emissions of city, especially the economy of relatively developed cities, such as Beijing etc., have been under control and get certain effect. Under the condition of the serious environmental pollution, those cities utilize the approach of green innovation-driven that converts the input resources to the maximum utilization ratio of desired output resources. In some areas its green innovation ability is insufficient. On the one hand, such as Ningxia and Xinjiang, which have low emissions, less population, underdeveloped technology level, scarce talents, but nature own strong self-purification ability. On the other hand, the provinces such as Shanxi and Neimenggu, where is due to the waste of energy and the neglect of carbon dioxide emissions.

In all provinces, the values of unexpected output in CCR model are higher than SBM model. It is illustrated that the output of environmental pollution can boost the development of the economy, so it can't be ignored. Although some provinces' two efficiency values are very close, such as Beijing, Shanghai, Shandong and Tianjin, said that these provinces' economic development has been set the concept of green development into that, it can be said that the environment governance has a certain effect. But in the other provinces gap of two efficiency value are relatively large, such as Hebei, Shanxi, Neimenggu, etc. It can be clearly seen, the result of SBM model with unexpected output value are far lower than the efficiency without environmental pollution output value, indicating that these provinces' economic development have not yet the concept of green development among them, and the technical level in these areas is relatively low, meantime they are lack of green innovation.

\section{The relationship between the carbon dioxide emission and across the middle income trap}

China plans to peak its carbon dioxide emissions around 2030 and will take more measures to reach an early peak. For the optimized zones with demonstration effect, which have peaked in 2011 and gradually slowed down, the non-optimized zones was increasing year by year. For the three optimized areas, the carbon dioxide emissions are lower than the key development areas, and the time of the carbon dioxide emission peak is earlier than the key development area.

As far as the current carbon dioxide emissions are concerned, China must drive economic growth through green innovation in order to achieve the peak target of China. This is a path to reduce carbon dioxide emissions, to promote economic growth, and to jump out of the middle income trap. In order to intuitively discuss the relationship between peak and carbon emissions, carbon dioxide emissions are fitted with per capita GDP in MATLAB. The results are shown in Figure 1.

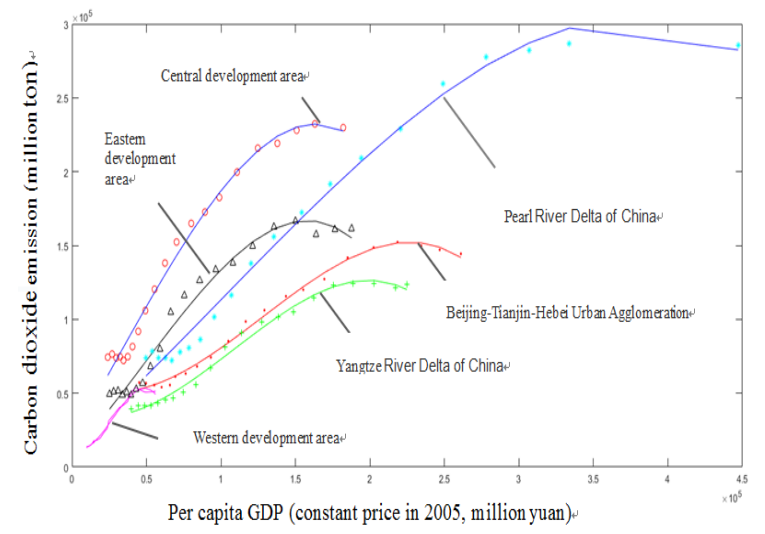

Fig. 1. Fitting of total carbon dioxide emissions with per capita GDP.

From Figure 1, we can see that with the development of economy and society, the results between carbon dioxide emissions and GDP exhibit the inverted U-shape pattern associated with the Environmental Kuznets Curve (EKC) hypothesis. When the per capita GDP 
reaches a certain value, carbon dioxide emissions will peak and then decrease. This trend is in line with the concept of green development whose economic growth is not at the cost of environmental pollution. China's economy is changing from high speed to "new normal", and the speed of economic growth is slowing down. The proportion of the general processing industry has declined, the proportion of technology intensive industries has increased, and especially the proportion of electrical machinery and equipment manufacturing, electronic and communication manufacturing industry has increased significantly.

In order to avoid the middle-income trap problems, it is necessary for China to optimize the regional development as the guide, and give demonstration to help other regions, in order to explain the correlation between China Carbon dioxide emissions' peak and jumping out of the middle-income trap. In order to achieve the peak goal, this paper demonstrates innovation ability from two perspectives. South Korea has been out of the middle-income trap which used the basis for the analysis of the possibility for China. Firstly, the tendency of patents number changed with time can be used to reflect the development of technology and to judge the innovation of technology. Secondly, the ratio of R\&D to GDP is the basic method to measure the innovation ability of a region.

In terms of the number of patents ${ }^{\mathrm{a}}$, Taiwan, China now has reached the level of well-developed countries in terms of the number of patents, such as the United States and Japan, where China, Hong Kong, Korea and Singapore cannot compete. For China, the experience of Asian countries that jump out of middle income traps is the best example. In these areas, patent technology has become the leader of the world, which is attributed to excellent intellectual property protection mechanism, R\&D expenditure support, and the transformation of technology imitation and import technology into independent technological innovation ${ }^{[9]}$. In the field of patent protection and application, China has issued a lot of strategic plans in 2017. The attention to the patent is obviously improved, and the Talent and Innovationdriven development strategy is realized.

The ratio of $R \& D^{b}$ to GDP is the basic method to measure the innovation ability of a region. China's growth rate increased from $0.6 \%$ in 1995 to $1.3 \%$ in 2003 , and has been growing since the 21 st century. It has reached $2.1 \%$ in 2015 . It is the second largest $R \& D$ investment country in the world behind the US, and also unique in middle-income countries. It is precisely because of the large amount of investment in research and development, the number of Chinese patents has also increased sharply, and the average growth rate of domestic innovation patents is also increasing. In 2015, the number of patents granted by China in the United States patent and trademark office (USPTO) exceeded 8000 pieces. It is far higher than other middle-income

\footnotetext{
a Source: USPTO report.

https://www.uspto.gov/web/offices/ac/ido/oeip/taf/reports.htm

${ }^{b}$ Source: World Bank the ratio of R \& D data to GDP.

http://date.worldbank.org.cn/indicator/GB.XPD.RSDV.GD.ZS
}

countries, and surpasses Israel who was called the "innovative country". In terms of the growth rate of patents, the growth rate in 2010 reached $64 \%$, and the growth has slowed down since then.

\section{Conclusions}

According to the current carbon dioxide emission status, it is concerned that the non-optimized zones have a great potential for reducing carbon dioxide emission. The reason is that the energy structure of non-optimized zones did not have completely converted. Firstly, using of non-renewable resources, such as coal and oil, is common. Secondly, it is Primary Industry and Second Industry, especially the Second Industry that plays a leading role in non-optimized zones' economic growth. For the optimized zones, they perform excellently in the two aspects. If we want to further reduce carbon dioxide emissions, we must start with green innovation.

There is great correlation between green innovation efforts and carbon emissions peak, reducing carbon dioxide emissions cannot be at the cost of economic development, and appear enormous environmental issues, while also face middle-income countries economic stagnation problem -- the middle-income trap. So the theory of green innovation is the key to solve the two problems. How to attain green innovation? On the one hand, the patent research and development should be considered energy conservation, environmental protection and green development. On the other hand, there is a need for policy support and strict enforcement. We should take the optimized zones as a model and learn its advanced low carbon dioxide technology. At the same time, it can also attribute other areas, so that China could solve the problem of carbon dioxide emissions peaking and jump out of the middle income trap as soon as possible.

\section{Acknowledgements}

The work was supported by the National Social and Scientific Fund of China (16AGL002), Major Program of the Ministry of Education (16JZD014). Special thanks are given to the anonymous reviewers for their incisive and comprehensive comments and suggestions.

\section{References}

1. A. P. Moniroth. The East Asian Economic Development Report. R., Washington D. C. . World Bank, (2006)

2. F. Gabriel Im. Middle-Income Traps. A Conceptual and Empirical Survey.R. Working Paper NO.6594, Washington D. C... World Bank, (2013)

3. H. Kharas. What Is the Middle Income Trap, Why do Countries Fall into It, and How Can It Be Avoided? J. Global Journal of Emerging Market Economies. 3(3): 281-289. (2011)

4. H. Erken. Why emerging economies are (un)successful in avoiding the middle income trap. 
R. Rababank Raboresearch-Economic Research. (2017)

5. B. Eichengreen. From Miracle to Maturity: the growth of the Korean Economy. M.President and Fellows of Harvard College, (2012)

6. Scherngell. Effects of knowledge capital on total factor productivity in China: A spatial econometric perspective. J. China Economic Review. (29): 82-94. (2014)

7. Brandt. WTO Accession and Performance of Chinese Manufacturing Firms. R. CEPR Discussion Paper N. 9166. (2012)

8. N. Bloom. Identifying technology spillovers and product.J. Econometrica, 81(4): 1347-1393. (2013)

9. B. Eichengreen. When fast growing economies slow down: International evidence and implications for China. R. NBER Working Paper. No. 16919. (2011) 